\title{
A simple rearing system for Thrips setosus Moulton (Thysanoptera: Thripidae) using a leaf cage method for the transmission experiment of tomato spotted wilt tospovirus
}

\author{
Jun Ohnishi, Daijirou Hosokawa, Tamotsu Murai ${ }^{1}$ and Shinya Tsuda ${ }^{2, *}$ \\ Faculty of Agriculture, Tokyo University of Agriculture and Technology, Fuchu, Tokyo 183-8509, Japan \\ ${ }^{1}$ Research Institute for Bioresources, Okayama University, Kurashiki, Okayama 710-0046, Japan \\ ${ }^{2}$ Plant Biotechnology Institute, Ibaraki Agricultural Center, Ibaraki 319-0292, Japan
}

(Received 14 December 1998; Accepted 16 June 1999)

\begin{abstract}
We have developed a simple rearing system for Thrips setosus to facilitate the collection and maintenance of a large number of even-aged for use in transmission experiments of tomato spotted wilt tospovirus. The system was established using a leaf cage. The leaf cage consisted of an excised leaf of the plant, Vigna susquipedaris, sandwiched between two acrylic plastic plates held by rubber bands. The upper plate had a 25 $\mathrm{mm}$-diameter hole in the center and two air ventilation holes, while the lower plate was flat. In this cage, approximately $75 \%$ of the total egg number could be collected during the first $6 \mathrm{~h}$ of a $24 \mathrm{~h}$ oviposition period, indicating that the first $6 \mathrm{~h}$ of the oviposition period is practical to collect eggs efficiently using this method. On day 6 after egg oviposition, $54.4 \%$ of the total number of hatched larvae was observed in the former half of the photophase (within $8 \mathrm{~h}$ after onset of the photophase), suggesting that this period is efficient for collection of larvae with synchronized age. This method was useful not only to collect a lot of synchronously hatched first instar larvae, but also to maintain them until adulthood without escape from the cage.
\end{abstract}

Key words: Thrips setosus, leaf cage method, tomato spotted wilt tospovirus, virus transmission

\section{INTRODUCTION}

Thrips setosus (Moulton) is one of the vectors of tomato spotted wilt tospovirus (TSWV) (Kobatake et al., 1984; Fujisawa et al., 1988), a type species of the Tospovirus genus of the family Bunyaviridae (Murphy et al., 1995). Tospovirus is the only plant virus group shown to be transmitted by thrips in a persistent manner (German et al., 1992). It has been reported that at least nine species of thrips can transmit TSWV (Mound, 1996). The occurrence of TSWV associated with $T$. setosus in Japan was first reported by Kobatake et al. (1976). Since the initial report, tospoviruses have been sporadically found in various crops throughout Japan (Tsuda, 1994). The manner by which tospovirus is transmitted is unique among insect-plant virus systems, because the virus is transmitted by thrips adults if acquired during the larval stage (Sakimura, 1962).
Since virus acquisition during the larval stage is a prerequisite for adult thrips transmission, the TSWV transmission experiment requires a large number of even-aged larvae, and the maintenance of infected larvae until the adult stage. However, caged whole plants, used for virus transmission experiments of $T$. setosus, present some difficulties in collection and maintenance. Therefore, development of a simple rearing system for $T$. setosus is necessary to establish an effective TSWV transmission experiment. Tashiro (1967) could maintain the citrus thrips, Scirtothrips citri (Moulton), on excised citrus leaves under artificial conditions using a modified Munger's cell (Munger and Gilmore, 1963). However, it has been utilized neither for the examination of TSWV transmission by $T$. setosus nor for collecting and maintaining the larvae. By adapting it for $T$. setosus with some modifications, we developed a simple rearing system to facilitate the TSWV transmission ex-

${ }^{*}$ To whom correspondence should be addressed at: Tel: +81-299-45-8330, Fax: +81-299-45-8351, E-mail: stsuda@mxj.mesh.ne.jp 
amination.

\section{MATERIALS AND METHODS}

In the present study, the cage created by Tashiro (1967) was modified the components and the construction for collecting eggs, for maintaining eggs until hatching, and for rearing larvae until the adult stage. The components of the cage we modified are illustrated in Fig. 1. We designated this modified cage as the leaf cage. It was simple as compared with Tashiro's cage and air ventilation holes were added to reduce the high humidity in the confined rearing area. The cage had two $75 \mathrm{~mm} \times 100 \mathrm{~mm}$ acrylic plastic plates of $9 \mathrm{~mm}$ thickness. The upper plate had a hole with a diameter of $25 \mathrm{~mm}$ in the center of the plate and two air ventilation holes with a diameter of $3 \mathrm{~mm}$ from both $100 \mathrm{~mm}$ sides of the plate down to the center hole. A piece of 180 mesh nylon screen was bonded to each opening of the air ventilation holes facing the center hole to prevent the escape of thrips from the cage. A wet filter paper was centered on the lower plate, and a fresh detached Vigna susquipedaris leaf was set on the paper. The upper plate was placed on the leaf and secured to the lower plate with rubber bands. The center hole of the upper plate was sealed with a thin glass slide.

The colonies of $T$. setosus were reared on caged $V$. susquipedaris pods under laboratory conditions of $24 \pm 1^{\circ} \mathrm{C}$ with a $16 \mathrm{~h}$ photophase and an $8 \mathrm{~h}$ scotophase cycle. Females were collected from the caged plants and subjected to the following experiments. On days 3 to 5 after adult eclosion, 20 females were transferred to the hole in the cage and allowed to lay eggs on the leaf for $24 \mathrm{~h}$ from the onset of the photophase. During the $24 \mathrm{~h}$ period, the number of eggs was counted at $6,12,18$ and $24 \mathrm{~h}$ after the onset of the photophase under a stereomicroscope by illuminating the leaf with a transmitted light. The eggs were incubated at $24 \pm 1^{\circ} \mathrm{C}$ with a $16 \mathrm{~h}$ photophase and an $8 \mathrm{~h}$ scotophase cycle until hatching. The hatchability was analyzed on the 5th, 6th and 7 th days after oviposition. The number of larvae hatched in the photophase and scotophase on days 5, 6 and 7 was counted. Three replications were conducted.

\section{RESULTS AND DISCUSSION}

The total number of eggs laid by 20 females

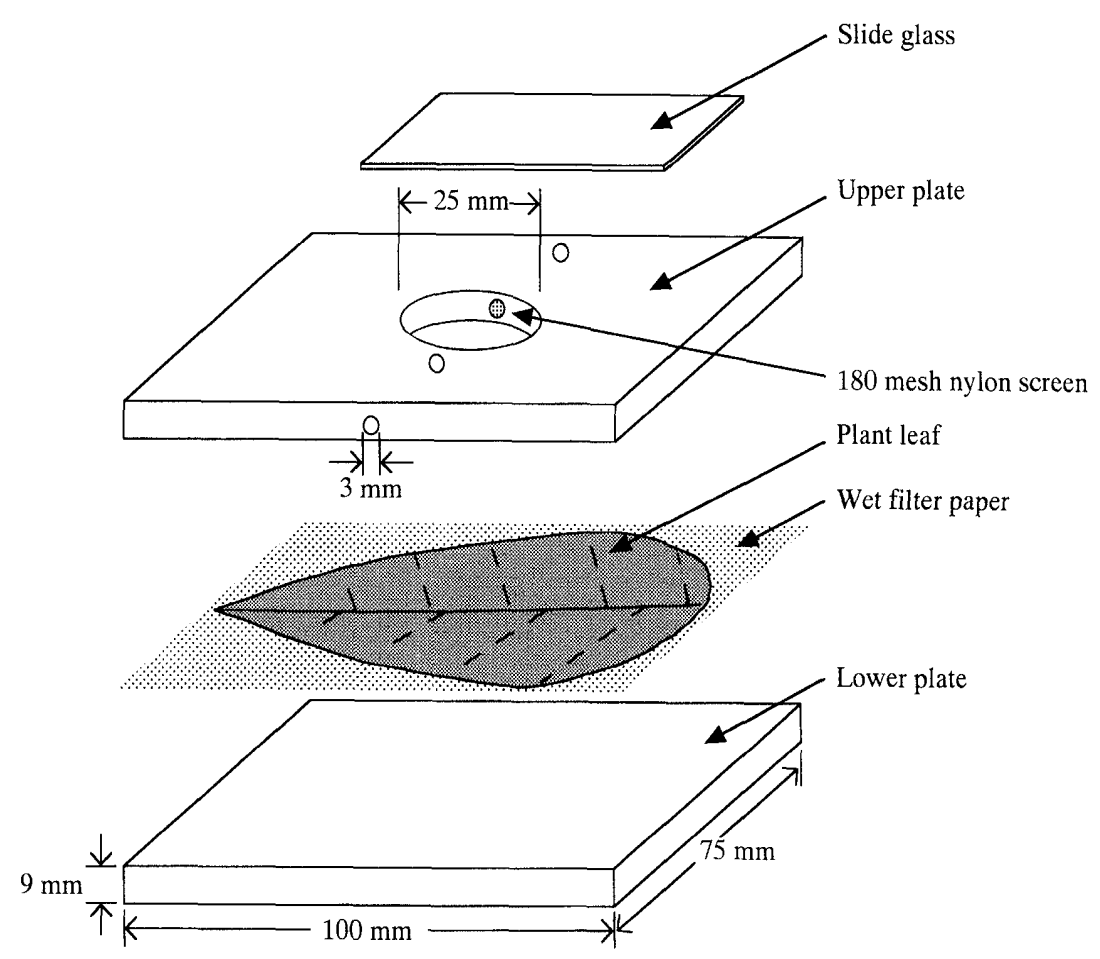

Fig. 1. The leaf cage developed for TSWV transmission experiment of Thrips setosus. The leaf was sandwiched between two acrylic plastic plates by securing with rubber bands, and the center hole of the upper plate was sealed with a slide glass to prevent the escape of insects. 


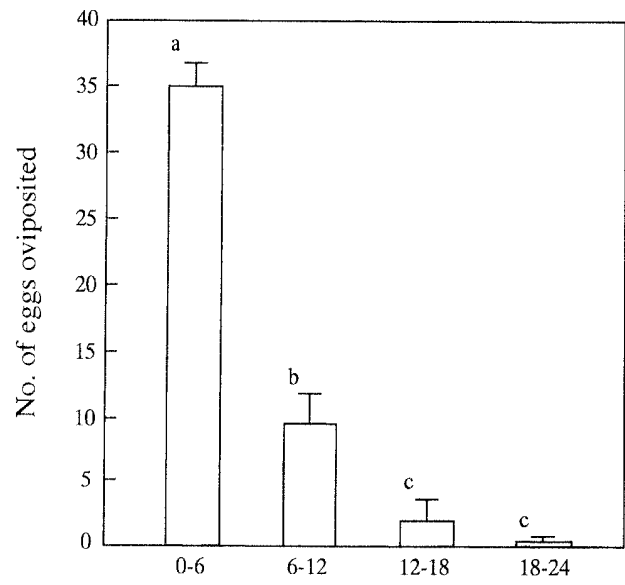

Hours after onset of the photophase

Fig. 2. Temporal change in the number of eggs laid by 20 female Thrips setosus during the $24 \mathrm{~h}$ oviposition period. The experiment was begun at the onset of the photophase at $24 \pm 1{ }^{\circ} \mathrm{C}$ with a $16 \mathrm{~h}$ photophase and $8 \mathrm{~h}$ scotophase cycle. Data represent average numbers of eggs counted for three independent experiments. The error bars represent standard deviations. Bars with different letters were significantly different at $p=0.05$ (Scheffé's multiple range test). during the $24 \mathrm{~h}$ oviposition period was $46.6 \pm$ 0.5 (mean $\pm \mathrm{SD}, n=3$ ) by the leaf cage method. Figure 2 shows the temporal change in the mean number of eggs observed in this study. There was a significant difference in the mean number of eggs during the $24 \mathrm{~h}$ (ANOVA, $F=210.5$, $\mathrm{df}=3,8, p<0.0001$ ). Approximately $75 \%$ of the total egg number was laid during the first 6 $h$, suggesting that the first $6 \mathrm{~h}$ period was a practical time to collect eggs efficiently by this method. The average hatchability of eggs laid by females during the $24 \mathrm{~h}$ oviposition period was $87.8 \%$. The mean numbers of hatched larvae on the 5 th, 6 th and 7 th days were $8.0 \pm$ 5.6, 30.0 \pm 4.4 and 3.0 \pm 5.2 , respectively (ANOVA, $F=24.1, \mathrm{df}=2,6, p<0.01$ ). The number on the 6th day was significantly higher than that on the 5th and 7th day (Scheffé's multiple range test, $p<0.01$ ). On the 6th day, $54.4 \%$ of the total number of hatched larvae was observed in the former half of the photophase (within $8 \mathrm{~h}$ after the onset of the photophase), although there was no significant difference in the mean number of hatched larvae
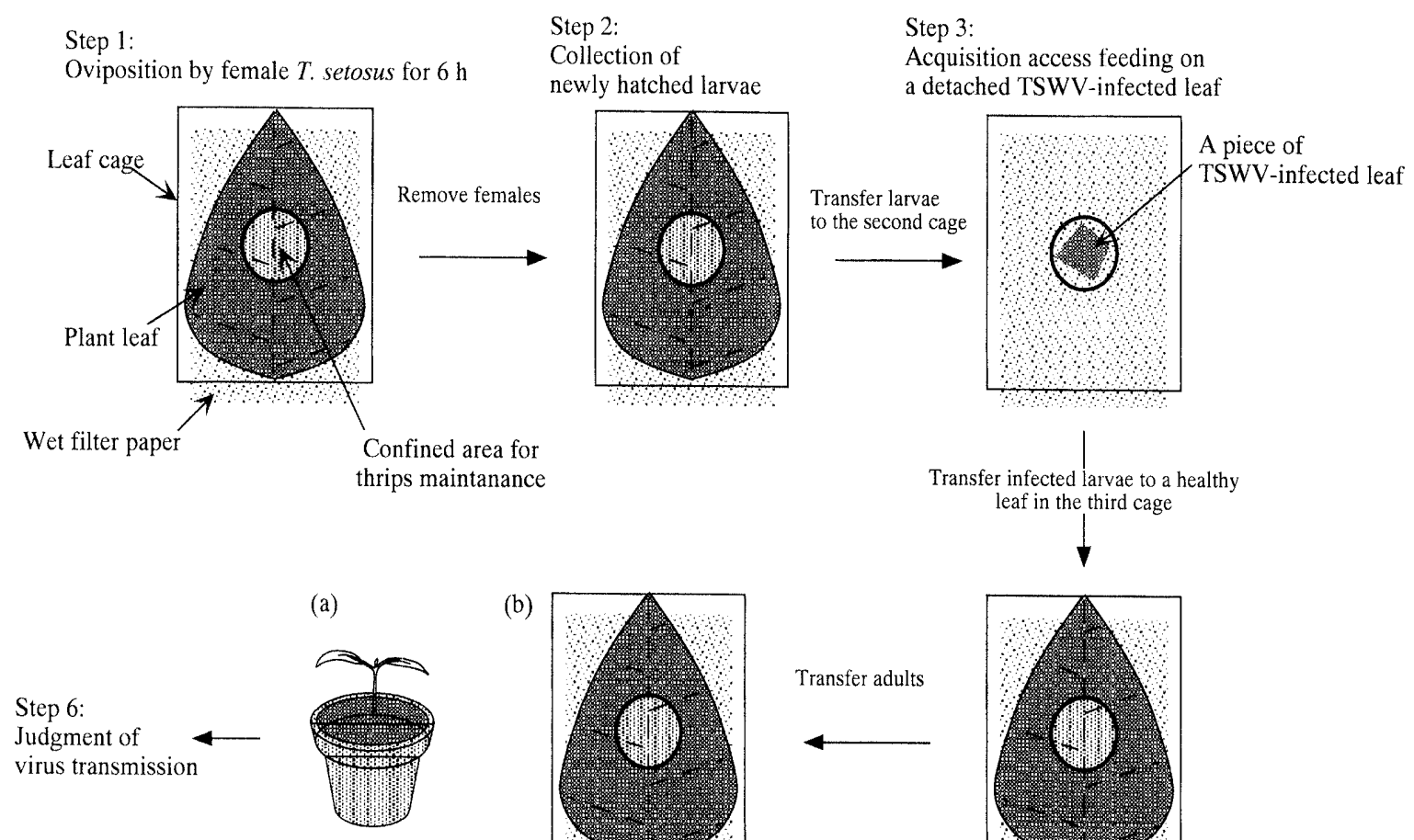

(b)
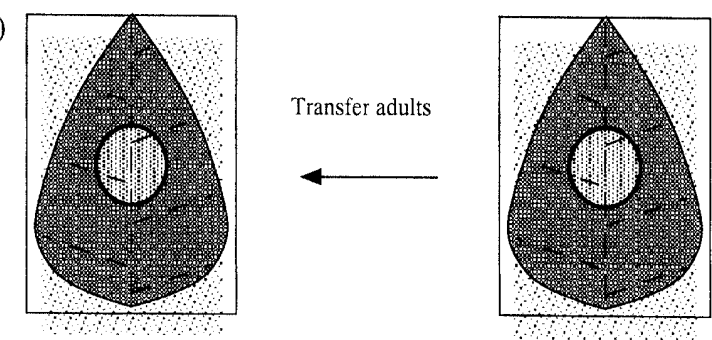

Step 5:

Inoculation access feeding on a whole plant host (a) or a detached leaf (b)

Step 4:

Maintainenance of infected larvae to adult stage on a healthy leaf

Fig. 3. Sequential steps of a novel experimental system for TSWV transmission by $T$. setosus with the leaf cage established in the present study. 
among the former half $(16.3 \pm 5.1)$, the later half $(5.3 \pm 5.1)$ of the photophase, and the scotophase (8.3 \pm 8.0 ) (ANOVA, $F=2.5, \mathrm{df}=2$, 6 , ns). Also, more than $2 \mathrm{~h}$ acquisition access feeding under the photophase condition is necessary for $T$. setosus larvae to acquire TSWV on the virus-infected plant (Fujisawa, personal communication). These facts suggested that the former half of the photophase on day 6 after oviposition was an efficient period for the collection of larvae of synchronized age and for the subsequent TSWV acquisition by the larvae. Since TSWV is transmitted by adult thrips allowed acquisition access feeding during the larval stage (Sakimura, 1962), it is necessary to maintain infected larvae to adulthood in a confined cage. By using the leaf cage, we could confine thrips and prevent their escape from the leaf surface. Furthermore, this system provided a suitable condition to maintain $V$. susquipedaris leaves for 2 weeks. Thus, we succeeded not only in collecting first instar larvae of synchronized age but also in achieving complete larval development to the adult stage.

One plan of sequential steps for the TSWV transmission experiment under $24 \pm 1^{\circ} \mathrm{C}$ with a $16 \mathrm{~h}$ photophase and $8 \mathrm{~h}$ scotophase cycle is as follows (see also Fig. 3): (1) oviposition by female $T$. setosus for $6 \mathrm{~h}$ in the first leaf cage. (2) collection of the newly hatched larvae within the first $8 \mathrm{~h}$ of the photophase on day 6 after the oviposition period. (3) acquisition access feeding by larvae for at least $2 \mathrm{~h}$ on a TSWV-infected leaf in the second leaf cage. (4) maintenance of infected larvae on a healthy leaf in the third cage. (5) inoculation access feeding by viruliferous adult thrips on virus susceptible systemic plants or their leaves. And (6) judgment for virus transmission by TSWV symptom expression.

The system developed in the present study requires less handling of insects and less space as compared with the maintenance of TSWVinfected thrips on a caged plant pod. It would be convenient for rearing $T$. setosus larvae and TSWV transmission experiments, and therefore be highly advantageous for further studies on tospovirus and thrips interactions.

\section{ACKNOWLEDGEMENTS}

We wish to thank L. Knight (University of California, Berkeley) for proofreading of the manuscript. We also thank Dr. T. Sakurai (Tohoku National Agricultural Experiment Station) for his suggestions on statistical analyses.

\section{REFERENCES}

Fujisawa, I., K. Tanaka and M. Ishii (1988) Tomato spotted wilt virus transmissibility by three species of thrips, Thrips setosus, Thrips tabaci and Thrips palmi. Ann. Phytopathol. Soc. Jpn. 54: 392 (Proceeding volume in Japanese).

German, T.L., D.E. Ullman and J.W. Moyer (1992) Tospoviruses: diagnosis, molecular biology, phylogeny, and vector relationships. Ann. Rev. Phytopathol. 30: 315-348.

Kobatake, H., T. Osaki and T. Inouye (1984) The vector and reservoirs of tomato spotted wilt virus in Nara prefecture. Ann. Phytopathol. Soc. Jpn. 50: 541-544.

Kobatake, H., T. Osaki, A. Yoshioka and T. Inouye (1976) Spotted wilt disease of tomatoes in Japan. Ann. Phytopathol. Soc. Jpn. 42: 278-294.

Mound, L.A. (1996) The thysanoptera vector species of tospovirus. Acta Horti No. 431: 298-309.

Munger, F. and J.E. Gilmore (1963) Equipment and technique used in rearing and testing the citrus red mite. In Advances in Acarology (J.A. Naegele ed.). Comstock Publishing Associates, Cornell University Press, Ithaca, New York, pp. 157168.

Murphy, F. A., C. M. Fauquet, D. H. L. Bishop, S. A. Ghabrial, A. W. Jarvis, G. P. Martelli, M. A. Mayo and M. D. Summers (eds.) (1995) Virus taxonomy: Classification and nomenclature of viruses. Arch. Virol. Suppl. 10: 586 pp.

Sakimura, K. (1962) The present status of thrips-borne viruses. In Biological Transmission of Disease Agents (K. Maramorosch ed.). Academic Press, New York, pp. 33-40.

Tashiro, H. (1967) Self-watering acrylic cages for confining insects and mites on detached leaves. J. Econ. Entomol. 60: 354356.

Tsuda, S. (1994) Tomato spotted wilt virus occurred in Japan and its properties. Shokubutu Boeki 48: 497-501 (in Japanese). 